\title{
Eksistensi Penganut Hindu Kaharingan dalam Menjaga Kerukunan Umat Beragama di Kota Palangka Raya
}

\author{
Susi \\ IAHN Tampung Penyang Palangka Raya \\ susiku1190@gmail.com
}

\begin{tabular}{|c|c|}
\hline $\begin{array}{l}\text { Riwayat Jurnal } \\
\text { Artikel diterima: } 15 \mathrm{~A} \\
\text { Artikel direvisi: } 17 \mathrm{Ju} \\
\text { Artikel disetujui: } 25 \mathrm{~J}\end{array}$ & \\
\hline $\begin{array}{l}\text { Kata Kunci: } \\
\text { Hindu Kaharingan, } \\
\text { Kerukunan umat } \\
\text { beragama }\end{array}$ & $\begin{array}{l}\text { Abstrak } \\
\text { Bahasan terkait pluralisme menawarkan toleransi dalam } \\
\text { menjaga kerukunan umat beragama. Problematika garis besar } \\
\text { penduduk Kota Palangka Raya berlatarbelakang aneka ragam } \\
\text { suku, agama, ras, antar golongan sangat berpolemik dan } \\
\text { menimbulkan masalah jika berada pada kondisi masyarakat yang } \\
\text { tidak rukun. } \\
\text { Tujuan penulisan ini mencoba untuk mengurai sosial } \\
\text { masyarakat individu maupun kelompok di Kota Palangka Raya } \\
\text { yang hidup berdampingan pada suatu wilayah dengan menjunjung } \\
\text { tinggi nilai-nilai kerukunan dan toleransi antar sesama di tengah- } \\
\text { tengah perbedaan masyarakat pluralis yang mencolok. Artikel ini } \\
\text { merupakan hasil dari sebuah penelitian kecil yang merupakan } \\
\text { penelitian lapangan dengan menggunakan metode kualitatif. } \\
\text { Untuk memperoleh data dilakukan dengan observasi dan } \\
\text { wawancara. Hasil temuan dapat disimpulkan bahwa interaksi } \\
\text { umat beragama di Kota Palangka Raya sangat rukun. Keberadaan } \\
\text { penganut Hindu Kaharingan di Kota Palangka Raya salah satunya } \\
\text { ikut ambil bagian menjaga kerukunan umat beragama sebagai } \\
\text { bentuk sikap responsif menghadapi persoalan kritis masyarakat } \\
\text { yang majemuk. Konflik yang timbul akibat diferensiasi } \\
\text { masyarakat tentu sewaktu-waktu bisa saja terjadi, namun } \\
\text { pelaksanaan kerukunan hidup dengan mengamalkan trilogi } \\
\text { kerukunan hidup umat beragama sebagai strategi yang dilakukan } \\
\text { demi mewujudkan rasa persatuan dan kesatuan masyarakat Kota } \\
\text { Palangka Raya yang kian dinamis seiring perkembangan zaman. }\end{array}$ \\
\hline $\begin{array}{l}\text { Keyword: } \\
\text { Hindu Kaharingan, } \\
\text { Religious Harmony }\end{array}$ & $\begin{array}{l}\text { Abstract } \\
\text { The development of religious harmony is a tool to unite the } \\
\text { nation in pluralist and pluralistic social conditions. The outline of } \\
\text { the population of Palangka Raya City consists of various } \\
\text { ethnicities, religions, races, between groups living side by side in } \\
\text { an area in harmony and participating in upholding tolerance }\end{array}$ \\
\hline
\end{tabular}




\begin{tabular}{|l|l|}
\hline $\begin{array}{l}\text { between people. The importance of maintaining harmony in a } \\
\text { pluralistic society so that every element of society needs to play an } \\
\text { active role in managing and realizing peaceful, harmonious and } \\
\text { harmonious living conditions. } \\
\text { The existence of Hindu Kaharingan adherents in Palangka } \\
\text { Raya City, takes part in maintaining religious harmony in } \\
\text { Palangka Raya City as a form of responsiveness in facing critical } \\
\text { problems of a pluralistic society. Conflicts that arise due to } \\
\text { societal differentiation can occur at any time. Therefore, the } \\
\text { implementation of harmony in life by practicing the trilogy of } \\
\text { religious harmony is a strategy carried out in order to create a } \\
\text { sense of unity in the people of Palangka Raya City, which is } \\
\text { increasingly dynamic with the times. }\end{array}$ \\
\hline
\end{tabular}

\section{Pendahuluan}

Indonesia sangatlah unik dan beragam, ada berbagai macam suku, agama, ras, adat istiadat yang berasal dari seluruh wilayah dari sabang sampai merauke memberikan warna bagi wajah Negara Indonesia. Pluralisme adalah kata yang cocok untuk menggambarkan karakteristik khas bangsa Indonesia. Kesadaran nasional akan perbedaan yang ada tak menjadikan Indonesia terpecah belah. Keunikan inilah yang membuat Indonesia berbeda dengan Negara-negara lain di dunia.

Karakteristik Indonesia sebagai bangsa yang majemuk dan heterogen didukung pendapat ahli (Nasikun, 1995: 29) bahwa masyarakat Indonesia memiliki struktur masyarakat yang majemuk (plural societies). Hal tersebut ditandai dengan adanya struktur yang unik, tercermin dari strukturnya yaitu secara horizontal dan vertical. Horizontal karena Indonesia memiliki keanekaragaman agama, suku, ras serta kedaerahan. Sedangkan, dikatakan vertical karena adanya lapisan masyarakat kelas atas dan kelas bawah.

Struktur masyarakat Indonesia yang majemuk dikelompokkan secara vertical dan horizontal serta kondisi ekologis wilayah di masing-masing daerah akan memberi tantangan tersendiri bagi Indonesia. Tak dapat dipungkiri Indonesia dengan fakta masyarakatnya yang plural dan heterogen dapat berpotensi untuk saling bersitegang hingga mampu menciptakan potensi konflik akibat keanekaragaman di wilayah Indonesia itu sendiri.

Kota Palangka Raya merupakan representasi pluralisme dari sisi keanekaragaman umat beragama di Indonesia. Hal ini karena hampir semua agama yang diakui di Indonesia bahkan aliran kepercayaan bisa ditemukan di kota ini. Berdasarkan data dari Dinas Kependudukan dan 
Catatan Sipil Kota Palangka Raya, pada tahun 2020 penduduk Palangka Raya sebanyak 199.140 beragama Islam, 5.511 beragama Katholik, 73.641 beragama Protestan, 3.453 beragama Hindu, 485 beragama Budha, 8 beragama Kong Huchu, dan 27 Aliran kepercayaan.

Realitas di atas menunjukkan bahwa Palangka Raya merupakan daerah kota yang pemeluk agamanya majemuk. Di tengah masyarakat yang majemuk maka setiap elemen masyarakat perlu berperan aktif mengelola dan mewujudkan kondisi kehidupan yang damai, harmonis, dan selaras. Hal ini sebab kemajemukan masyarakat memiliki dua potensi yang berbeda, diantaranya di satu sisi merupakan kekuatan karena merupakan perpaduan dari berbagai macam latar belakang budaya dan keunggulan yang saling melengkapi sesuai dengan ciri Bhinekka Tunggal Ika dan di sisi lain perbedaan tersebut berpeluang pula terhadap timbulnya perselisihan dan perpecahan.

Konflik dengan latar belakang masyarakat yang heterogen memang pernah terjadi di beberapa wilayah Indonesia, termasuk di wilayah Kalimantan Tengah. Diketahui Kalimantan Tengah adalah kewilayahan yang ikut secara aktif mendukung upaya menjaga keutuhan wilayah NKRI. Bingkai persatuan dan kesatuan yang ada di Kalimantan Tengah menggambarkan miniatur Indonesia dengan keunikan masyarakatnya dengan latar belakang berasal dari beragam suku, agama, ras, maupun adat istiadat. Namun, wilayah Kalimantan Tengah sendiri pernah mengalami konflik antar etnis yang terjadi antara Suku Dayak asli dengan Suku Madura yang peristiwa puncaknya terjadi di tahun 2001-an silam. Tentu hal ini menjadi bukti persitegangan yang terjadi di antara kelompok masyarakat dengan latar belakang masyarakat yang berbeda-beda. Perlu dimaklumi bahwa konflik antar kelompok masyarakat yang majemuk menjadi peristiwa yang berulang kali terjadi lagi setiap tahunnya, walaupun dengan intensitas, skala, dan latar belakang pemicu konflik yang berbeda-beda dari segi intern dan ekstern. Peristiwa-peristiwa konflik yang sudah terjadi menjadi pelajaran yang tidak boleh dibiarkan terulang kembali dalam sejarah mengingat implikasi yang merugikan dan mencederai keutuhan nilai-nilai persatuan dan kesatuan yang dibangun sejak lama.

Keberadaan penganut Hindu Kaharingan mewujudkan kerukunan umat beragama di Kota Palangka Raya demi mengantisipasi dan merespon persoalan di tengah-tengah masyarakat terkait masalah-masalah yang berkaitan dengan kondisi masyarakat yang majemuk. Melalui langkah strategis dengan menekankan pada menjaga kerukunan umat beragama sebagai upaya mendukung kokohnya nilai-nilai persatuan dan kesatuan, wujud nyata eksistensi masyarakat penganut Hindu Kaharingan yang ada di Kota Palangka Raya khususnya. 
Masalah yang didalami dalam tulisan ini adalah bagaimana eksistensi masyarakat Hindu Kaharingan menjaga kerukunan umat beragama di Kota Palangka Raya. Adapun tujuanya adalah mendeskripsikan keberadaan kelompok penganut Hindu Kaharingan yang sudah berintegrasi dengan agama Hindu dalam menjaga kerukunan hidup umat beragama di Kota Palangka Raya. Tulisan ini dapat menjadi sumbangsih upaya dan sikap yang melatarbelakangi penerapan kebijakan berkaitan pembinaan kerukunan hidup umat beragama khususnya wilayah yang ada di Kota Palangka Raya.

\section{Pembahasan}

\section{Eksistensi Penganut Hindu Kaharingan}

Eksitensi penganut Hindu Kaharingan dalam kerukunan hidup umat beragama khususnya wilayah yang ada di Kota Palangka Raya tidak terlepas dari kepercayaan lokal yang sudah berkembang sejak lama. Nilai-nilai luhur tatu hiang (nenek moyang) tentang ajaran Kaharingan banyak memberikan sumbangsih di kehidupan sosial kemasyarakatan. Hal ini terutama kajian tentang kepercayaan penduduk asli suku Dayak di Kalimantan Tengah sebagai penelitian menarik yang telah banyak dilakukan peneliti lokal dan internasional. Sebagaimana menurut Riwut (2003: 478) menjelaskan bahwa kepercayaan asli suku Dayak adalah kepercayaan Helu atau Kaharingan. Kaharingan berasal dari kata haring artinya hidup, dengan demikian Kaharingan mempunyai pengertian kehidupan.

Berbicara eksistensi Hindu Kaharingan tentu ada realitas penganut kepercayaan agama Helu/Kaharingan yang kini sudah berintegrasi masuk ke dalam Hindu sebagai sebuah agama Hindu lokal yang diakui di Kota Palangka Raya secara khusus. Hindu Kaharingan menunjukkan bahwa terdapat hubungan yang harmonis antara pemeluk agama dengan masingmasing agama lainnya yang non Hindu. Keharmonisan hubungan antar umat beragama terjadi secara alamiah dan telah berlangsung sejak lama.

Melihat perkembangan Hindu Kaharingan sebenarnya baru familiar dua dasawarsa yang cukup dinamis di Kota Palangka Raya. Keyakinan asli masyarakat Suku Dayak yang dengan ciri khas pelaksanaan ritus-ritus upacara keagamaan yang sakral yang membedakannya dengan daerah-daerah lain di Indonesia. Namun, tidak jarang ada pihak yang non Dayak masih keliru menyebut Kaharingan sebagai bagian dari adat dan ajaran kuno yang ada di Kalimantan Tengah. Hal ini dijelaskan Etika bahwa sejak namanya dikenal pada era 1970-an, Kaharingan dipahami beragam oleh masyarakat luas, bahkan oleh orang yang tinggal di Kalimantan itu sendiri, karena banyaknya suku yang ada di Kalimantan, nama Kaharingan pun dianggap sebagai salah satu anak suku dari Dayak, yaitu Dayak Kaharingan (2019: 1). 
Penyebutan bagi penganut Hindu Kaharingan yang populer sekarang diketahui sebenarnya muncul dari kata 'Kaharingan' juga disampaikan Sagiyarto (2016: 107) dalam tulisannya menyebut Kaharingan berasal dari bahasa Sangen, dari akar kata "Haring" berarti "ada dan tumbuh". Dalam istilah Danum Kaharingan artinya air kehidupan, dilambangkan Batang Garing atau Pohon Kehidupan. Istilah Kaharingan diperkenalkan menjelang kemerdekaan tahun 1945 oleh Dai Nippon, atas saran tokoh adat Dayak Ngaju, Damang Y. Salilah dan W. A. Samat pada waktu Tjilik Riwut menjadi Residen Sampit. Kaharingan sudah menjadi agama bagi suku Dayak, seperti agama lain, meskipun belum ada pembukuan ayatayat dari Ranying Hatala Langit saat itu.

Pada tataran ini penulis mengobservasi dan berpandangan bahwa agama Hindu dan keyakinan lokal suku Dayak di masa lalu justru tidak menyebabkan konflik antar umat-umat beragama lain di Palangka Raya. Namun, ada beberapa riak-riak kecil sumber konflik ini justru berasal dari intern umat yang masih belum menerima status integrasi antara Kaharingan dengan agama Hindu sehingga ingin memisahkan diri dari Hindu. Namun, lepas dari hal itu kondisi social masyarakat Hindu Kaharingan maupun yang memilih menganut kepercayaan Kaharingan sebenarnya tidak jauh berbeda dalam hal ajaran keagamaannya. Bahkan di beberapa pelaksanaan ritual keagamaan juga menunjukkan bahwa tampak keharmonisan interaksi yang positif diantara pemeluk Hindu Kaharingan dengan sesamanya. Sebagai contoh, ritual keagamaan Hindu Kaharingan ataupun yang mengakui kepercayaan agama Helu/Kaharingan masih sama-sama berpedoman pada ajaran Kaharingan/Helu di masa lalu setiap pelaksanaan acara-acara keagamaannya. Penganut Hindu Kaharingan juga masih mengutamakan nilai-nilai kekeluargaan dan hidup rukun agar konflik-konfilik intern dan ekstern tidak terjadi.

Pelaksanaan suatu agama adalah titik tolak dari kepercayaan manusia kepada Tuhan dan tidak lepas daripada kepercayaan agama tersebut kepada ajaran ketuhanannya. Sama halnya dengan penganut kepercayaan Kaharingan atau Agama Helu. Pelaksanaan ajaran keagamaan memang sudah berkembang sejak lama dilaksanakan hingga kini sebagai warisan nenek moyang suku Dayak. Konflik ektern yang bisa saja terjadi dimana ketidaktahuan masyarakat non Hindu yang mempengaruhi perspektif masyarakat awam non Dayak terkait ajaran-ajaran keagamaan Hindu Kaharingan. Bahkan jika melihat sekilas tentu ada perbedaan antara religius dan profan dalam kebudayaan masyarakat suku Dayak asli yang tidak begitu jelas. Oleh karena itu, perspektif dan cara pandang dalam mempelajari tentang ke-Tuhanan 
pada semua agama tidaklah sama, meskipun semuanya mengakui hanya ada satu tuhan. Hal ini pun juga berlaku bagi penganut Kaharingan dalam pengamalan dan pelaksanaan ajaran keagamaannya di kehidupan sehari-hari.

Hal ini diakui salah satu pejuang/tokoh integrasi Hindu Kaharingan yang menurutnya bahwa Kaharingan selama ini selalu dianggap sebagai bagian adat yang usang dan kepercayaan kuno. Bahkan dalam perkembangannya para pemeluk kepercayaan Kaharingan banyak beralih agama. Dinamika Kaharingan di wilayah Kalimantan Tengah sebenarnya mengalami pasang surut terkait identitas keberadaan mereka di mata hukum pemerintahan yang berlaku. Kaharingan sampai seperti sekarang telah melalui proses yang panjang untuk diakui sebagai agama dan memperoleh legalitas di mata hukum dengan berintegrasi pada Hindu. (Wawancara Lewis KDR, 25 Maret 2021).

Perihal integrasi yang terjadi antara Hindu dan kepercayaan Kaharingan diungkapkan Walter S. Penyang, Ketua MB-AHK Pusat Kota Palangka Raya (2018) yang dikutip dalam wawancara resmi dengan Media Center, bahwa "Integrasi adalah sebuah refleksi sejarah perjuangan suku Dayak khususnya dari kepercayaan Kaharingan di Kalimantan pada era tahun 1980-an. Integrasi adalah peringatan bersatunya agama Kaharingan dengan agama Hindu. Hal itu didasarkan pada persamaan teologis dan filosofis".

Perjuangan para tokoh Kaharingan dilihat dari dinamika penganut Kaharingan sebelum integrasi yang mengalami kesulitan di masa lalu. Gaya (2016: 143-144) dalam penelitiannya bahwa:

Hambatan pra integrasi yang dialami kesulitan penganut Kaharingan seperti kesulitan menjadi Pegawai Negeri, kesulitan mendapat pendidikan agama dari jenjang pendidikan dasar sampai pendidikan tinggi. Bahkan puncak ketidakadilan yang dialami umat penganut Kaharingan pada tahun 1979 adalah diskriminasi dan desakan untuk mencantumkan agama pada pengisian KTP. Adanya kebijakan Pemerintah yang hanya mengakui 5 agama yakni Islam, Kristen, Katolik, Hindu, dan Budha, menambah kesulitan masyarakat penganut kepercayaan Kaharingan menjalani ajaran kepercayaan yang sudah diyakini sejak dulu. Dua pilihan yang diberikan pihak pemerintah bagi penganut Kaharingan/Agama Helo, yaitu pertama saran untuk memilih agama yang ada, memilih salah satu agama dari 5 (lima) agama yang sudah diakui serta dibina oleh Departemen Agama. Pilihan kedua adalah tetap menganut kepercayaan Kaharingan yang masuk pada jalur kepercayaan yang dibina oleh Departemen Pendidikan dan Kebudayaan.

Para pejuang dan tokoh-tokoh pemeluk Kaharingan/agama Helo meyakini integrasi dengan Hindu maka akan memiliki kebebasan beribadah dan beribadat sesuai dengan agama dan kepercayaan yang dianut sebagaimana bunyi kebebasan beragama yang tertuang pada Pasal 29 UUD RI Tahun 1945. Hindu menjadi agama yang cocok dan memiliki kesamaan dengan ajaran penganut agama Helu/Kaharingan, serta tidak bertentangan dengan keyakinan 
suku Dayak di masa lalu. Hindu memberikan tempat bagi Kaharingan untuk tetap mempertahankan tradisi leluhur (tatu hiang) dengan syarat tidak bertentangan dengan kitab suci Veda.

Bukti perjalanan Kaharingan dijelaskan Etika (2019: 2) bahwa segala usaha atau upaya terus ditempuh oleh para tokoh Kaharingan, walaupun adanya distorsi yang serius dari pihak luar, terhadap penganut Agama Kaharingan, melalui penolakan terhadap pelaksanaan berbagai bentuk ritual keagamaan dengan pemberian nama yang menyakitkan dan penghinaan, menyebutkan umat Kaharingan adalah penganut aliran kepercayaan, ritual yang dilaksanakan sebagai pemujaan kepada berhala, dan orang-orang yang menganut tradisi leluhur Kaharingan disebut berdosa dan primitif.

Agama Hindu sudah tentu pilihan yang tepat kala itu sebahai jalan berintegrasinya Kaharingan dengan memilih masuk ikut Agama Hindu. Karakteristik keberagamaan yang tidak jauh berbeda antara Hindu dan Kaharingan juga turut menjadi alasan bergabung dengan Hindu. Pasca Integrasi bagi penganut Kaharingan yang tidak ingin meninggalkan agama kepercayaan leluhurnya pun masih menyebut dirinya Kaharingan/Hindu Kaharingan/Hindu. Keinginan berintegrasi masuk Hindu memang keinginan murni dari masyarakat pemeluk Kaharingan dan tokoh-tokoh pejuang Kaharingan yang di Kalimantan Tengah. Sehingga agama Hindu mewadahi penganut Kaharingan dengan memberikan hak dan kebebasan beragama.

Integrasi dimulai sejak tahun 1980 dan dengan dikeluarkannya Surat Edaran PHDI Provinsi Kalimantan Tengah Nomor: I/E/PHDI-KH/1980 perihal tata cara pelaksanaan upacara keagamaan yang telah dilakukan Kaharingan sebagai upacara agama Hindu tetap dipelihara dan dilestarikan, sepanjang tidak bertentangan dengan Weda/Panaturan, dan Peraturan perundang-undangan yang berlaku di Republik Indonesia.

Dinamika perkembangan Hindu Kaharingan selama proses dan pasca integrasi penganut Kaharingan dengan penganut agama Hindu banyak upaya dilakukan guna membangun kehidupan keberagamaan yang lebih baik. Antisipasi terkait isu integrasi yang mungkin melatarbelakangi konflik bahwa Agama Hindu akan mem-Bali-kan penganut Kaharingan ditepis dengan edaran PHDI tersebut di atas. Kerukunan sesama umat beragama terjalin sebab Hindu memberikan wadah bagi penganut Kaharingan menjalankan dan melaksanakan ritual upacara keagamaan yang sudah ada sejak lama sebagai warisan leluhur (tatu hiang). Perlu dipahami lagi bahwa konteks integrasi terkait Hindu dan Kaharingan bukanlah menghilangkan diferensiasi, karena yang terpenting adalah kesadaran untuk 
memelihara menjaga keseimbangan untuk menciptakan hubungan sosial yang harmonis dalam kehidupan umat seagama demi terjalinnya kerukunan di antara sesama dan antarumat beragama.

Sugiyarto (2016: 104) dalam tulisannya mendukung pula bahwa sejatinya semua adalah agama tua Nusantara keluarga besar Hinduisme. Ritual dan tradisinya sebagai manifestasi ajaran mengalir dari pusatnya, yaitu Veda. Pelaksanaan tradisi dari masa lampau sebagai warisan agama tradisional yang harus dijaga kelestariannya dan tidak bertentangan dengan ajaran Veda. Dengan demikian, wajar saja perkembangan Hindu sangat diterima masyarakat Kalimantan Tengah khususnya dan bersahabat dengan daerah-daerah di mana Hindu berkembang. Perkembangan Hindu yang dinamis dan fleksibel dengan kebiasaan setempat tidak bertentangan dengan kebiasaan-kebiasaan masyarakat yang sudah berkembang sejak lama.

Hindu secara umum dan Hindu Kaharingan yang ada di Kalimantan Tengah mengganggap perbedaan sebagai karakteristik yang unik dari penganut Hindu Nusantara. Perbedaan praktek keagamaan Hindu di Indonesia bahkan bukan hanya terjadi di wilayah Kalimantan Tengah yang masih memeluk kepercayaan Kaharingan. Hindu yang ditemukan di banyak wilayah, misalnya Marapu, Nauru, Alok Todolo, Hoaulu, Naulu, Tolottang, dan sebagainya juga memiliki perbedaan dengan Hindu aslinya. Hal yang terpenting dari sisi mana kita melihat diferensiasi yang ada sehingga tidak menimbulkan gesekan intern dan ekstern yang memicu konflik di kemudian hari. Pemeluk Hindu harus berwawasan luas dan terbuka, bersama-sama saling menerima, menghargai dan saling melengkapi, karena praktik keagamaan Hindu itu sejatinya menyesuaikan dengan desa, kala, dan patra.

Praktik keagamaan yang dilakukan penganut Hindu Kaharingan dalam eksistensinya selama ini sebagian besar terdapat dan berdasar atas petunjuk, pedoman dan ajaran yang diajarkan secara lisan maupun tertulis dari leluhur/nenek moyang (tatu hiang), bahkan termasuk di dalamnya yang termuat dan dinarasikan kitab Panaturan yang tidak bertentangan dengan Kitab Veda. Ada beberapa tata cara, budaya, kebiasaan yang telah membudaya dalam kehidupan masyarakat di Kota Palangka Raya yang tidak jauh berbeda dengan Hindu pada umumnya. Pelaksanaan ajaran keagamaan tetap dilaksanakan sebagai bagian kekayaan identitas, kearifan lokal, adat istiadat, budaya dari nilai-nilai luhur yang diwariskan oleh nenek moyang sejak dahulu kala dan kini dipertahankan keasliannya oleh penganut Hindu Kaharingan sebagai wujud eksistensi penganut Hindu Kaharingan dalam dinamikanya di era kekinian. 


\section{Kehidupan Keagamaan Penganut Hindu Kaharingan di Kota Palangka Raya}

Kota Palangka Raya adalah pusat pemerintahan ibukota Provinsi Kalimantan Tengah. Secara administrasi pemerintahan (BPS Kota Palangka Raya, 2019: 3), wilayah Kota Palangka Raya memiliki 5 (lima) wilayah kecamatan yaitu Kecamatan Sabangau,Kecamatan Jekan Raya, Kecamatan Bukit Batu dan Kecamatan Rakumpit yang terdiri dari 30 Kelurahan.

Komposisi penduduk di Kota Palangka Raya merupakan gabungan antara berbagai macam suku baik suku Dayak dengan berbagai macam sub-sub sukunya maupun suku lain yang berasal dari luar wilayah Provinsi Kalimantan Tengah. Sumbangan yang sangat besar terhadap adanya etnis lain di Kota Palangka Raya salah satunya tidak terlepas dari adanya program transmigrasi yang dilakukan oleh Pemerintah guna pemerataan dan pengurangan kepadatan penduduk di wilayah-wilayah yang telah padat penduduknya seperti Pulau Jawa dan Bali.

Masyarakat Kota Palangkaraya memiliki banyak sekolah agama, rumah ibadah dan tokoh agama. Klasifikasi jumlah penduduk berdasarkan agama menurut data Dinas Kependudukan dan Pencatatan Sipil pada tahun 2020 penduduk Palangka Raya sebanyak 199.140 beragama Islam, 5.511 beragama Katholik, 73.641 beragama Protestan, 3.453 beragama Hindu, 485 beragama Budha, 8 beragama Kong Huchu, dan 27 Aliran kepercayaan (BPS Kota Palangka Raya, 2020: 154-155).

Melihat data kependudukan tersebut maka diketahui sebagian besar penduduk di Kota Palangka Raya adalah penganut Agama Islam. Banyaknya penganut Agama Islam di Kota Palangka Raya karena komposisi penduduk di wilayah ini selain penduduk asli banyak juga suku pendatang terutama suku Banjar dan Jawa yang mayoritas menganut Islam ditambah lagi sebagian dari penduduk asli yang beragama Islam.

Dari keseluruhan jumlah pemeluk agama di Kota Palangka Raya maka penganut Hindu di Kota Palangka Raya menduduki urutan ke-4 (empat). Kecilnya jumlah penganut Hindu di Kota Palangka Raya menunjukan bahwa suku Dayak asli telah banyak yang meninggalkan agama asli mereka (Kaharingan/Agama Helo) yang diwariskan oleh nenek moyang (tatu hiang). Setelah Hindu, dalam sensus penduduk yang dilakukan juga masih terdapat aliran kepercayaan menduduki urutan ke-6 (enam) lebih banyak jumlahnya dari Konghucu. Hal ini menunjukan bahwa ada suku Dayak asli yang belum menerima atau mengakui integrasi agama asli (Kaharingan/Agama Helo) ke dalam Hindu sehingga mereka dalam pendataan agama dimasukkan ke dalam kelompok aliran kepercayaan. 


\section{Kerukunan Umat Beragama Hindu di Kota Palangka Raya}

Manusia ditakdirkan sebagai makhluk sosial yang membutuhkan hubungan dan interaksi sosial dengan sesama manusia. Manusia selalu berinteraksi satu dengan lainnya, menjalin kerja sama dengan orang lain guna memenuhi kebutuhan hidupnya baik kebutuhan secara material dan spiritual. Ajaran Hindu pun mengajarkan manusia dalam sosial kemasyarakatan selalu mengamalkan ajaran agamanya dengan baik, memupuk sradha dan bhakti kehadapan Ida Sang Hyang Widhi Wasa/Tuhan Yang Maha Esa, mengutamakan pengamalan dharma dalam berkarma, memupuk sikap cinta kasih dan tolong menolong antar sesama dalam hal kebaikan.

Agama-agama lainnya yang non Hindu juga mengajarkan penganutnya untuk berbuat yang baik dan benar sesuai ajaran agama yang dianutnya. Sama halnya dalam menjaga kerukunan beragama. Kerukunan beragama perlu ditingkatkan semua umat beragama guna terciptanya keharmonisan dan kedamaian manusia dalam kehidupan sosial kemasyarakatannya.

Pada bagian ini konsep kerukunan adalah istilah yang dipenuhi oleh muatan makna "baik" dan "damai". Hakikatnya, hidup bersama dalam masyarakat dengan "kesatuan hati" dan "bersepakat" untuk tidak menciptakan perselisihan dan pertengkaran (Depdikbud, 1985: 850). Bila pemaknaan tersebut dijadikan pegangan, maka "kerukunan" adalah sesuatu yang ideal dan didambakan oleh masyarakat manusia. Kerukunan sebagai wujud suasana persaudaraan dan kebersamaan antar semua orang walaupun mereka berbeda secara suku, agama, ras dan antargolongan.

Sikap rukun antar sesama adalah wujud pengamalan ajaran agama itu sendiri yang harus diinternalisasikan dalam pribadi masing-masing sejak dini. Bahkan selama ini wacana pemerintah dalam pembinaan kerukunan umat beragama adalah program yang sejak lama diupayakan guna menangkal konflik terkait isu SARA, terutama yang menyangkut hal agama dan kepercayaan.

Nazmudin (2017: 27) menjelaskan dalam rangka pembinaan dan pemeliharaan kerukunan hidup umat beragama, sejak beberapa tahun yang lalu Departemen Agama bahkan mengembangkan pendekatan tiga kerukunan (Trilogi Kerukunan) yaitu: Kerukunan Intern Umat Beragama, Kerukunan Antarumat Beragama dan Kerukunan Antarumat Beragama dengan Pemerintah. Pelaksanaan kegiatan kerukunan agama di atas adalah tugas yang telah dicanangkan Departemen Agama sebagai upaya pembinaan keagamaan di Indonesia. 
Temuan penelitian menunjukan bahwa terdapat tiga faktor yang turut mempengaruhi kerukunan umat beragama Hindu di Kota Palangka Raya. Pertama, kerukunan yang menyangkut intern umat Hindu Kaharingan. Maka perlunya diselenggarakan musyawarah intern umat beragama dan kegiatan-kegiatan yang memupuk rasa persatuan dan kesatuan dalam kalangan intern penganut Hindu Kaharingan.

Kegiatan kerukunan intern umat dimaksud bahwa kehidupan sosial kemasyarakatan umat Hindu Kaharingan memiliki latar belakang penganut Hindu yang heterogen yang berasal dari sub-sub suku Dayak dari seluruh wilayah di Kalimantan Tengah. Faktanya penganut Hindu Kaharingan bukan hanya berasal dari satu wilayah tetapi berasal dari berbagai wilayah yang tersebar di seluruh wilayah Kalimantan Tengah tentu memiliki keragaman yang berbeda-beda di satu wilayah dengan wilayah lainnya. Kegiatan pertemuan dan kegiatan-kegiatan lainnya yang sifatnya intern Hindu Kaharingan ditujukan agar tidak terjadi perselisihan dan perdebatan menyangkut diferensiasi pelaksanaan ajaran keagamaan di masing-masing daerah. Komunikasi terbuka di kalangan intern adalah kunci menghindari sikap intoleransi intern sesama penganut Hindu Kaharingan khususnya di Kota Palangka Raya.

Upaya menyatukan konsepsi tentang kesamaan ajaran Hindu Kaharingan tentu bukan hal yang mudah disampaikan pada masyarakat awam. Apalagi terkait perbedaan pola pikir, bahasa dan adat-istiadat setempat yang dimiliki menjadi salah satu kendala yang dihadapi. Ajaran Hindu kemudian mewadahi perbedaan yang ada pada penganut Hindu Kaharingan dengan mengajarkan konsep desa, kala, patra. Hindu bahkan memberikan kesempatan dan kebebasan pemeluk Hindu Kaharingan untuk melestarikan dan melaksanakan ajaran warisan leluhurnya (tatu hiang). Pengamalan ajaran-ajaran asli suku Dayak masa lampau adalah bagian kepercayaan para penganut Kaharingan yang kini tumbuh dan berkembang cukup dinamis di wilayah setempat. Ajaran penganut Hindu Kaharingan diyakini ajaran suci yang bersumber dari Ranying Hatalla/Tuhan Yang Maha Esa.

Intern penganut Hindu Kaharingan harus memahami konsep desa, kala, patra sebagai kelenturan interpretasi masyarakat pada suatu wilayah dalam kurun waktu tertentu yang disesuaikan dengan situasi/keadaan tertentu. Sehingga konsep ini menjadikan tradisi kuno sebagai warisan yang lentur, fleksibel dan menjawab kebutuhan jaman. Selain itu, pertemuan intern penganut Hindu Kaharingan dapat berwujud pelaksanaan persembahyangan rutin Basarah yang dilakukan setiap hari Kamis atau malam Jumat pada Balai Basarah/Tempat persembahyangan Hindu Kaharingan. Kegiatan persembahyangan pada Balai Basarah Umum 
di Jalan Tambun Bungai Palangka Raya yang diadakan setiap minggunya pada hari Kamis atau malam Jumat sebagai bentuk pembinaan kerukunan intern Hindu Kaharingan secara khusus di wilayah Kota Palangka Raya.

Persembahyangan rutin secara bersama-sama intern penganut Hindu Kaharingan contohnya melalui Basarah adalah upaya peningkatan keimanan dan ketakwaan kepada Ranying Hatalla/Tuhan Yang Maha Esa. Pemupukan rasa persatuan dan kebersamaan dalam menjalankan tata cara beribadat yang sama menurut Hindu Kaharingan. Basarah selalu diikuti oleh penganut Hindu Kaharingan yang berasal dari berbagai daerah di Kalimantan Tengah. Tata cara dalam rangkaian pelaksanaan Basarah memberikan nuansa kerukunan intern penganut Hindu Kaharingan karena kesamaan dalam tata cara beribadat memuja Ranying Hatalla/Tuhan Yang Maha Esa. Tidak jarang ditemukan pelaksana Basarah dipimpin oleh penganut Hindu Kaharingan dari daerah yang berbeda-beda, bahkan petugas-petugas yang mengiringi rangkaian Basarah juga berasal dari DAS yang tidak sama. Hal tersebut bukan menjadi persoalan dan halangan bagi suksesnya pelaksanaan Basarah itu sendiri. Kegiatan persembahyangan Basarah intern penganut Hindu Kaharingan tetap terlaksana dengan baik dan lancar dari awal hingga berakhir.

Faktor yang mendukung kerukunan intern penganut Hindu Kaharingan adalah karakter pribadi/individu penganut Hindu Kaharingan itu sendiri. Oleh karenanya penting untuk memupuk sejak dini nilai-nilai kerukunan sehingga terbentuk dalam pribadi dan sikap penganut Hindu Kaharingan yang menjunjung tinggi toleransi umat beragama. Sikap antipati dan fanatisme yang memicu ketegangan dan konflik intern umat perlu dihindari. Penganut Hindu Kaharingan juga harus menjadi pribadi yang tebuka terhadap perbedaan. Terwujudnya kerukunan intern penganut Hindu Kaharingan tidak lain adalah demi terciptanya keharmonisan, keserasian, keselarasan dan kebahagiaan baik secara batiniah dan rohaniah.

Kedua, kerukunan antar umat beragama penganut Hindu Kaharingan yang ada di Kota Palangka Raya. Komposisi penganut agama di Kota Palangka Raya memiliki variasi jumlah pemeluk dengan perbandingan mayoritas dan minoritas. Pemeluk Hindu berada pada urutan ke-4 (empat) berdasarkan data BPS Palangkaraya Dalam Angka Tahun 2019. Ada yang berasal dari etnis Hindu Bali, Hindu Jawa, Hindu Kalimantan, sebagai pemeluk agama Hindu di wilayah Kota Palangka Raya

Pandangan Weinata Sairin (PPKHB, 1979: 39) bahwa sejatinya kerukunan otentik dimaksudkan bukanlah kerukunan yang diusahakan hanya oleh karena alasan-alasan praktis, pragmatis dan situasional. Tapi semangat kerukunan yang benar-benar keluar dari hati yang 
tulus dan murni, karena ia didorong oleh sesuatu keyakinan imaniah yang dalam sebagai perwujudan dari ajaran agama yang diyakini.

Secara umum, kehidupan sosial kemasyarakatan umat Hindu tidak pernah membedakan satu dengan lainnya. Agama Hindu memiliki ajaran yang universal dan tidak hanya berlaku bagi pemeluk agama Hindu tetapi agama non Hindu juga bisa melaksanakan ajaran Hindu apabila sesuai dan tidak bertentangan dengan ajaran agama yang dianutnya. Hindu sendiri selalu mewujudkan kerukunan antar umat beragama dengan salah satu konsep ajarannya yang terkenal "Vasudhaiva Kutumbakam". Vasudhaiva Kutumbakam memiliki pengertian seluruh dunia ini adalah satu keluarga tunggal. Dalam artian, dapat dimaknai bahwa seluruh umat manusia adalah bersaudara. Penganut Hindu terhadap pemeluk agama non Hindu adalah bagian dari saudara yang tidak terikat oleh ikatan pertalian darah tetapi adalah saudara karena bagian makhuk ciptaan Tuhan Yang Maha Esa. Keberadaan penganut agama non Hindu yang juga berasal dari beberapa wilayah berbeda di Kota Palangka Raya adalah bagian keragaman suku, agama, ras, antargolongan.

Keberadaan penganut Hindu Kaharingan di Kota Palangka Raya sebagai penduduk asli suku Dayak Kalimantan Tengah tentunya juga berasal dari berbagai sub suku dengan latar belakang adat-istiadat yang berbeda berbaur dengan masyarakat pemeluk agama non Hindu dengan latar belakang yang berbeda pula.

Kerukunan antar umat beragama penganut Hindu Kaharingan di Kota Palangka Raya dapat berwujud observasi, penelitian, kerjasama sosial kemasyarakatan, kegiatan bersama antar umat beragama dan lainnya. Bahkan seiring berjalannya waktu penganut Hindu Kaharingan maka cara keberagamaan penganutnya semakin matang.

Wujud kerukunan antar umat beragama penganut Hindu Kaharingan di Kota Palangka adalah observasi dan penelitian-penelitian yang mengkaji hubungan masyarakat lintas keagamaan dengan Hindu Kaharingan. Oleh karenanya penelitian-penelitian baik lokal dan internasional yang membahas kehidupan masyarakat suku Dayak di Kalimantan Tengah dan kepercayaan asli suku Dayak di masa lampau seperti Kaharingan/Agama Helo telah memberikan sumbangsih dalam bidang akademisi untuk memahami kehidupan keagamaan suku Dayak tempo dulu. Tujuannya melalui kajian akademis dan penelitian matang yang teruji mampu memberikan pemahaman sehingga masyarakat awam tidak salah tafsir dengan penganut Hindu Kaharingan. 
Adapaun bentuk lain kerukunan antar umat beragama yang sering ditemui di Kota Palangka Raya adalah kerjasama sosial kemasyarakatan yang tidak terikat, khususnya dalam pelaksanaan ritual keagamaan. Kerukunan antar beragama dengan mulai banyaknya penganut Hindu Kaharingan yang melangsungkan ritual keagamaan secara kolektif atau bersama-sama anggota keluarga yang berasal dari penganut non Hindu. Rasa kebersamaan diikuti kerjasama oleh anggota keluarga Hindu Kaharingan dan anggota keluarga/masyarakat non Hindu sehingga serta merta ikut berpartisipasi dan memberikan bantuan. Masyarakat non Hindu ikut menghormati satu sama lainnya baik dalam hal beribadat sesuai keyakinan yang dianutnya dan pengamalan ajaran keagamaan penganut Hindu Kaharingan.

Contohnya, sebut saja pelaksanaan ritus upacara kematian tingkat terakhir Hindu Kaharingan “Upacara Tiwah". Tidak jarang keluarga duka penganut Hindu Kaharingan yang melaksanakan upacara Tiwah dibantu oleh anggota keluarga/masyarakat yang beragama non Hindu Kaharingan. Upacara Tiwah sebagai upacara yang sakral dan membutuhkan biaya yang besar dan kerjasama semua pihak agar terlaksana dengan baik. Kerjasama yang tercipta tersebut berkat kebiasaan masyarakat asli suku Dayak yang menjunjung tinggi sikap handep hapakat (gotong-royong) antar satu dengan lainnya.

Istilah handep hapakat secara etimologis berasal dari bahasa Dayak Ngaju yang terdiri dari dua kata yaitu handep dan hapakat, Apabila masing-masing diartikan maka handep (Iper, 2009: 215) diartikan 'gotong royong'. Sedangkan, hapakat (Iper, 2009: 505) dari kata pakat yang berarti pakat; mupakat; setuju. Dapat diketahui bahwa handep hapakat yang diartikan sebagai tindakan saling gotong royong, saling bantu-membantu dan/atau saling bermupakat.

Entah kapan kebiasaan handep hapakat' ini dimulai sehingga sikap saling tolong menolong, bahu membahu meringankan beban keluarga duka yang melaksanakan ritus Upacara Tiwah dapat terlewati berkat kerjasama dan pertolongan tangan banyak pihak. Adapun Gaya (2020), menambahkan handep hapakat adalah ajaran Kaharingan yang terdapat dalam Kitab Panaturan. Sasanti 'penyang hinje simpei, paturung humba tamburak' yang dimaknai sebagai bersatu padu dalam memecahkan masalah agar tujuan tercapai (Hasil wawancara, 14 Maret 2020).

Kebiasaan gotong royong melekat untuk semua orang atau penduduk baik itu penduduk asli maupun penduduk pendatang yang baru menetap maupun yang sudah lama menetap di bumi Kalimantan Tengah khususnya. Sehingga tidak salah memang jikalau julukan Bumi Pancasila tercermin di wilayah Kalimantan Tengah secara khusus karena benar-benar menjunjung tinggi rasa kebersamaan dan persatuan pakat sebagai semua saudara tidak memandang suku, agama, ras dan antargolongan yang harus diberikan uluran pertolongan 
ketika membutuhkan bantuan dan/ atau mengalami kesulitan baik dalam keadaan suka dan duka.

Ketiga, adalah kerukunan umat beragama dengan pemerintah yang diwujudkan sebagai bentuk pembinaan keagamaan umat beragama di Kota Palangka Raya. Terciptanya kerukunan umat beragama dengan pemerintah dengan harapan mampu menjaga stabilitas nasional dalam rangka pembangunan bangsa yang bersatu padu. Pembinaan jalur ketiga ini dipengaruhi kerukunan intern dan antar umat beragama yang senantiasa mewujudkan hidup rukun dalam satu kesatuan yang utuh dalam trilogi kerukunan umat beragama.

Secara khusus, menjaga kerukunan umat beragama dengan pemerintah di Kota Palangka Raya maka dapat didukung dengan pekan maupun kegiatan organisasi umat beragama dengan pemerintah yang ada. Kerukunan umat beragama Hindu Kaharingan dengan pemerintah didorong kesadaran bahwa penganut Hindu Kaharingan berada di bawah naungan lembaga Majelis Besar Agama Hindu Kaharingan (MB-AHK) Pusat Palangka Raya. MB-AHK Pusat Kota Palangka Raya sebagai wadah musyawarah besar intern dan antar umat beragama yang memfasilitasi penganut Hindu Kaharingan untuk berkoordinasi dengan pemerintah perihal kegiatan-kegiatan keagamaan.

Selama ini menilik perjuangan para tokoh-tokoh Kaharingan di masa lalu untuk memperoleh legalitas dan pengakuan identitas di mata hukum yang berlaku tidak terlepas dari peran lembaga/perserikatan/organisasi. Lembaga-lembaga dimaksud seperti: Serikat Kaharingan Dayak Indonesia (SKDI), Majelis Besar Alim Ulama Kaharingan Indonesia (MBAUKI), Parisada Hindu Dharma Indonesia (PHDI), Majelis Besar Agama Hindu Kaharingan (MB-AHK) Pusat Palangka Raya dan lainnya untuk tetap teguh memperjuangkan hak penganut Kaharingan yang ada di Kalimantan Tengah, dan khususnya di Kota Palangka Raya.

Pemerintah bertanggung jawab mewadahi kebebasan dalam beribadat sesuai agama dan kepercayaan yang dianut sebagaimana bunyi Pasal 29 UUD 1945. Hal ini dimaksudkan karena trilogi kerukunan adalah satu kesatuan yang harus diciptakan dengan melibatkan segenap komponen bangsa baik pribadi, keluarga, masyarakat, dan pemerintah. Interaksi penganut Hindu Kaharingan dengan penganut non Hindu dari latar belakang masyarakat yang beragam melalui komunikasi intern dan antar umat beragama dengan tujuan terpeliharanya kerukunan intra dan antar umat beragama. Implikasi komunikasi yang intens lintas agama diharap mampu 
mewujudkan kehidupan yang damai, harmonis, saling menghormati, saling tolong menolong dan tercapainya kerukunan umat beragama dimaksud.

Pekan organisasi antar umat beragama dengan pemerintah di Kota Palangka Raya salah satunya melalui pertemuan-pertemuan bertajuk lintas agama, seminar nasional/internasional lintas agama, dialog/ diskusi lintas agama dengan melibatkan organisasi-organisasi lintas agama bersama-sama, masyarakat, tokoh-tokoh lintas agama dengan pihak pemerintahan yang menaungi kebijakan-kebijakan terkait keagamaan. Bahkan ada pula diadakan Utsawa Dharma Gita, Festival Tandak Intan Kaharingan (FTIK) dan Upacara Keagamaan penganut Hindu Kaharingan, yang acapkali bekerjasama dengan pemerintah daerah dan pemerintah pusat guna terjalinnya kebersamaan di antara penganut seagama.

Penganut Hindu Kaharingan telah mengenal falsafah belom penyang hinje simpei (hidup bersatu padu dalam ikatan kebersamaan) sebagai motto hidup warisan nenek moyang (tatu hiang). Upaya penerapan belom penyang hinje simpei dalam kehidupan sosial kemasyarakatan suku Dayak di masa silam ikut berkembang dalam kehidupan penganut Hindu Kaharingan dan non Hindu. Selain itu, falsafah hidup Huma Betang dengan ciri hidup berdampingan antar sesama digunakan sebagai inspirasi motto instansi-instansi kepemerintahan yang bekerja dan melayani masyarakat luas. Kearifan lokal yang berasal dari warisan nenek moyang (tatu hiang) kepercayaan asli suku Dayak di Kalimantan hingga kini masih terjaga dengan baik.

Pemerintah dalam kaitannya menjaga kerukunan umat beragama juga telah menerapkan pembinaan-pembinaan keagamaan yang ditujukan kepada masing-masing agama demi meningkatnya keimanan dan ketakwaan kepada agama yang dianut. Contoh peran pemerintah mendukung kerukunan intern umat beragama adalah edaran Pemda setempat bagi ASN penganut Hindu Kaharingan yang bekerja di instansi/ kantor-kantor pemerintahan diberikan wadah menjalankan ibadah dan persembahyangan sesuai ajaran agama yang dianutnya pada hari Jumat dalam bentuk Basarah ASN. Pemeluk agama Islam sekalipun misal terkait jam kerja di lingkungan instansi/ kantor pemerintahan juga diberikan kebebasan menjalankan syariat-syariat agama Islam tanpa mengganggu aktivitas jam kerja di kantor.

Bagi penganut Hindu Kaharingan sendiri, peran serta pemerintah mewujudkan jalinan kerukunan antar umat beragama melalui masing-masing Pemerintah daerah yang ada adalah pekan pelaksanaan Safari Hari Raya Nyepi, Safari Raya Hintan Kaharingan, dan Festival Tandak Intan Kaharingan yang dilaksanakan setiap tahunnya dengan bantuan dana dari pemerintahan. Momen ini guna terwujudnya jalinan persaudaraan dan kekerabatan intern dan antar umat beragama. Melihat dinamika perkembangan penganut Hindu Kaharingan masa kini 
maka toleransi antar sesama umat beragama pasca integrasi telah memberikan perubahan yang signifikan bagi kemajuan keberagamaan umat Hindu Kaharingan khususnya yang ada di Kota Palangka Raya.

Sejalan dengan penjelasan di atas, maka berbagai temuan lapangan di atas tentang pola kerukunan sesama dan antarumat beragama Hindu di Kota Palangka Raya menunjukkan bahwa interaksi penganut Hindu Kaharingan di kota ini cukup harmonis. Keharmonisan mengacu pada trilogi kerukunan umat beragama tersebut tetap terus terjaga meskipun dalam kondisi perbedaan masyarakat yang tidak dapat dihindari. Untuk menjaga kerukunan demi keharmonisan umat beragama dengan sikap yang ditunjukkan penganut keagamaan yaitu rasa kekeluargaan, toleransi, saling menghargai perbedaan yang dimiliki sebagai bagian dari kekuatan yang harus dibangun untuk bisa menghargai perbedaan dan menjadikannya sebagai perekat hubungan social secara khusus di kalangan penganut Hindu Kaharingan itu sendiri.

Di sisi lain, perkembangan zaman yang kian dinamis tentunya memberi tantangan sekaligus hambatan bagi terciptanya keselarasan antar umat beragama. Mengingat ajaran Hindu yang begitu adiluhung ditambah ajaran Kaharingan yang menempatkan nilai kemanusiaan di atas segalanya dari masa lampau mewarnai keberadaan penganut Hindu Kaharingan di masa kini. Perlu diperhatikan dan menjadi tanggung jawab semua pihak baik intern, antar umat beragama, dan antara umat beragama dengan pihak pemerintah sehingga mampu menjadi poin-poin sentral menjaga kerukunan hidup umat beragama. Sehingga melalui pembinaan keagamaan yang berlandaskan trilogi kerukunan hidup umat beragama dapat menjadi langkah jitu mewujudkan kerukunan hidup masyarakat penganut Hindu Kaharingan yang ada di Kota Palangka Raya.

\section{Simpulan}

Berdasarkan analisis terhadap data dan temuan di lapangan, dapat disimpulkan bahwa kerukunan interaksi penganut Hindu Kaharingan dalam menjaga kerukunan umat beragama Hindu di Kota Palangka Raya ditopang oleh pedoman trilogi kerukunan umat beragama yang memungkinkan terjadinya hubungan harmonis hidup rukun intern umat beragama, antarumat beragama dan antarumat beragama dengan pemerintah. Hal ini teruji secara sadar, terencana, terarah, teratur, dan bertanggung jawab melalui menjaga kerukunan dan keharmonisan serta hidup berdampingan satu sama lainnya. Keluhuran ajaran kepercayaan agama Helu/Kaharingan setelah berintegrasi dengan Hindu menjadi sumber kekuatan integratif dan 
sumber nilai-nilai keagamaan yang telah mengakar dan diwariskan secara turun-temurun khususnya pada masyarakat Dayak penganut Hindu Kaharingan di masa kini. Perbedaan dalam agama dan kepercayaan sebagai ciri masyarakat Kota Palangka Raya yang pluralis maka dalam budaya Dayak tidak dipandang sebagai bentuk pertentangan, tetapi sebagai hak asasi dan pilihan pribadi setiap orang. Keberadaan penganut agama yang berbeda-beda menjadikan topik kerukunan hidup beragama sebagai langkah yang harus disinergikan demi mencegah konflik yang mungkin timbul di kemudian hari. Dengan himbauan bagi masyarakat pendatang yang memiliki sikap radikalisme dan intoleransi agar mempelajari dan memahami budaya handep hapakat dengan falsafah hidup Huma Betang masyarakat Kota Palangka Raya khususnya dan Kalimantan Tengah umumnya yang dijuluki Bumi Pancasila.

\section{Daftar Pustaka}

Badan Pusat Statistik Kota Palangka Raya. (2021). Kota Palangka Raya Dalam Angka 2019. Palangka Raya: BPS Kota Palangka Raya.

Depdikbud. (1985). Kamus Besar Bahasa Indonesia. Jakarta: Balai Pustaka.

Etika, Tiwi. (2019). Perjuangan Kritis Agama Kaharingan di Indonesia: Tantangan Berat dan Masa Depan Agama Asli Suku Dayak. Jurnal Studi Kultural. 4 (1): 1-12.

Gaya. (2016). Integrasi Kepercayaan Kaharingan ke Dalam Agama Hindu di Kota Palangka Raya Kalimantan Tengah. Disertasi. Denpasar: IHDN.

Hefner, Robert W. (2005). "Social Legacies and Possible Future. John Bresnan (ed.) Indonesia: The Great Transition. Lanham: Rowman \& Littlefield Publisher Inc, pp. 75136.

Iper, Dunis. (2009). Kamus Bahasa Dayak Ngaju-Indonesia. Palangka Raya: Anugerah Indah Mandiri.

MB-AHK. (2017). Panaturan. Denpasar: Widya Dharma Denpasar.

Muhammad, Afif. (2013). Agama dan Konflik Sosial: Studi Pengalaman Indonesia. Bandung: Marja.

Nasikun. (1995). Sistem Sosial Indonesia. Jogjakarta: Fisipol UGM.

Nazmudin. (2017). Kerukunan dan Toleransi Antar Umat Beragama dalam Membangun Keutuhan Negara Kesatuan Republik Indonesia (NKRI). Journal of Government and Civil Society. 1 (1): 23-39.

Proyek Pembinaan Kerukunanan Hidup Beragama (PPKHB). (1979). Pedoman Dasar Kerukunan Hidup Beragama. Jakarta: Departemen Agama.

Riwut, Nila. (2003). Maneser Panatau Tatu Hiang. Yogyakarta: NR-Publishing.

Sagiyarto, Wakhid. 2016. Eksistensi Agama Hindu Kaharingan di Kota Palangkaraya Kalimantan Tengah. Jurnal Muktikultural \& Multireligius. 15 (3): 102-116.

Surat dari Direktorat Jenderal Bimbingan Masyarakat Hindu dan Budha Departemen Agama RI Nomor: H.III/1980 tentang Penggabungan/Integrasi Umat Kaharingan dengan Hindu.

Surat Edaran PHDI Provinsi Kalimantan Tengah Nomor: I/E/PHDI-KH/1980 tentang Tata Cara Pelaksanaan Upacara Keagamaan.

Walter S. Penyang. (2018). "Peringatan Integrasinya Agama Kaharingan Dengan Agama Hindu”. Media Center, diakses pada 14 Maret 2020 pada http://palangkaraya.go.id// 